\title{
The Relationship between Intolerance of Uncertainty and the Depression, Anxiety and Stress Levels of Nursing Students during the Covid-19 Outbreak
}

\author{
Covid-19 Pandemi Sürecinde Hemşirelik Öğrencilerinde \\ Belirsizliğe Tahammülsüzlük ile Depresyon, Anksiyete ve Stres \\ Düzeyleri Arasindaki İlişki
}

\author{
Sibel Şentürk ${ }^{1}$, Nazife Bakır ${ }^{2}$
}

\begin{abstract}
:
This study was conducted to determine the relationship between Turkish nursing students' intolerance of uncertainty and their depression, anxiety and stress levels during the COVID-19 outbreak. This descriptive and cross-sectional study was conducted between 18 and 29 May 2020, with the participation of 506 students. The data were collected using a Personal Information Form, the Intolerance of Uncertainty Scale (IUS-12) and the Depression, Anxiety and Stress Scale (DASS-21). It was found that the participants had a mean total IUS-12 score of $37.18 \pm 10.10$. When the subscales of DASS-21 were examined, the participants' mean scores were found to be $13.20 \pm 5.87$ for the 'depression' sub-scale, $10.76 \pm 3.94$ for the 'anxiety' sub-scale and $14.21 \pm 5.90$ for the 'stress' sub-scale. It was ascertained that there were statistically significant differences in the mean scores obtained by the participants in the overall IUS-12 and DASS-21 sub-scales on the basis of the variables of 'the nursing students' academic achievements' and 'how the nursing students felt during the COVID-19 pandemic' $(\mathrm{p}<0.05)$. It was discerned that there was a weak positive statistically significant relationship between the mean scores obtained in the overall IUS-12 and those obtained in the DASS-21 sub-scales $(\mathrm{p}<0.01)$. As the nursing students' intolerance of uncertainty increased, their depression, anxiety and stress levels also went up. Psychological counseling should be offered to nursing students to prevent them from having mental disorders, to identify their mental issues and to help them cope with these mental problems.
\end{abstract}

Keywords: COVID-19, Nursing Student, Intolerance of Uncertainty, Depression, Anxiety, Stress.

\footnotetext{
${ }^{1} \mathrm{RN}$, PhD, Department of Nursing, Bucak Health School, Burdur Mehmet Akif Ersoy University, Bucak-BurdurTurkey, Orcid İd: https://orcid.org/ 0000-0002-5634-174X

${ }^{2} \mathrm{RN}$, PhD, Department of Nursing, Bucak Health School, Burdur Mehmet Akif Ersoy University, Bucak-Burdu-Turkey, Orcid İd: https://orcid.org/ 0000-0003-1324-0647
}

Address of Correspondence/Yazışma Adresi: RN, PhD, Department of Nursing, Bucak Health School, Burdur Mehmet Akif Ersoy University, Bucak-Burdur-Turkey, E-mail: sibelsenturk@mehmetakif.edu.tr

Date of Received/Geliş Tarihi: 05.04.2021, Date of Revision/Düzeltme Tarihi: 10.05.2021, Date of Acceptance/Kabul Tarihi: 20.05.2021, Date of Online Publication/Çevirimiçi Yayın Tarihi: 01.06.2021

Citing/Referans Gösterimi: Șentürk, S., Bakır, N. (2021). The Relationship between Intolerance of Uncertainty and the Depression, Anxiety and Stress Levels of Nursing Students during the Covid-19 Outbreak, Cyprus Turkish Journal of Psychiatry \& Psychology, 3(2): 97-105

(C) 2021 The Author(s). Published by Cyprus Mental Health Institute / Cyprus Turkish Journal of Psychiatry and Psychology (www.ktppder gisi.com). This article is an open access article distributed under the terms and conditions of the Creative Commons Attribution 4.0 license which permits use, sharing, adaptation, distribution and reproduction in any medium or format, provided the original work is properly cited and is not used for commercial purposes. https://creativecommons.org/licenses/by-nc-sa/4.0/ 


\section{Öz:}

$\mathrm{Bu}$ araştırmanın amacı, COVID-19 pandemi sürecinde Türk hemşirelik öğrencilerinde belirsizliğe tahammülsüzlük ile depresyon, anksiyete ve stress düzeyleri arasındaki ilişkiyi belirlemektir. Tanımlayıcıkesitsel nitelikteki bu araştırma, 18-29 Mayıs 2020 tarihleri arasında 506 hemşirelik öğrencisi ile tamamlanmıştır. Veriler, Kişisel Bilgi Formu, Belirsizliğe Tahammülsüzlük Ölçeği (BTÖ) ve Depresyon Anksiyete Stres Ölçeği (DASS-21) ile toplanmıştır. Hemşirelik öğrencilerinin BTÖ toplam puan ortalaması $37.18 \pm 10.10$ 'dur. DASS-21'in alt ölçekleri incelendiğinde, DASS-21“depresyon" alt boyutu puan ortalamas1 $13.20 \pm 5.87$, "anksiyete" alt boyutu puan ortalaması $10.76 \pm 3.94$ ve "stres" alt boyutu puan ortalaması $14.21 \pm 5.90$ olarak belirlenmiş̧ir. Hemşirelik öğrencilerinin akademik başarı ve COVID-19 süresince kendini nasıl hissettiği değişkenleriyle BTÖ ve DASS-21 skalası alt boyutlarından aldıkları puan ortalamaları arasındaki fark istatistiksel olarak anlamlı bulunmuştur $(p<0,05)$. Öğrencilerin BTÖ toplam puanı ile DASS-21 skalası alt boyutları arasında ise zayıf yönde pozitif ilişki saptanmıştır $(p<0,01)$. Hemşirelik öğrencilerinin belirsizliğe tahammülsüzlükleri arttıkça depresyon, anksiyete ve stres düzeyleri de artmaktadır. Hemşirelik öğrencilerine mental sağlık sorunları yaşamalarını önlemek, mental sorunlarını tespit etmek ve bu mental sorunlarla baş etmelerine yardımcı olmak için psikolojik danışmanlık sunulmalıdır.

Anahtar Kelimeler: COVID-19, Hemşirelik Öğrencisi, Belirsizliğe Tahammülsüzlük, Depresyon, Anksiyete, Stres.

\section{Introduction}

The novel coronavirus 2019 (COVID-19 or 2019-nCoV) pandemic which emerged in the Wuhan city of China in December 2019 and took hold of the entire world by spreading rapidly has affected the lives of societies significantly (Zhu, Wei, \& Niu, 2020; Huang et al., 2020). Until 19 May 2021, since the World Health Organization (WHO) named the SARS-CoV-2 virus as the source of the novel coronavirus disease 2019 (COVID-19) and declared it as a pandemic by referring to it as a worrying international public health issue, more than 163.8 million COVID-19 cases have been reported, and it was determined that 3.3 million people lost their lives (WHO, 2021). It was reported that the total number of cases was 5.1 million, and the total number of deaths was 45.419 in Turkey since the announcement of the first case until the present (Republic of Turkey Ministry of Health, 2021).

The COVID-19 pandemic has affected higher education all over the world, in addition to all areas of life (Erkut, 2020; Karadağ \& Yücel, 2020). In this period, most governments across the world decided to close educational institutions down for the purpose of preventing the spread of the COVID-19 pandemic. As most countries started to put in place social distancing rules, a majority of tertiary education institutions were also obliged to adopt online learning, communicate remotely with faculty members and students and change their work styles in a short period of time (Pragholapati, 2020). In Turkey, in relation to these measures, firstly, education and instruction were suspended for three weeks as of 16 March 2020 in all universities affiliated with the Tertiary Education Council of Turkey (TEC). However, along with the uncertainty about the process of the pandemic and the increase in the number of cases, TEC announced on 26 March 2020 that the spring semester of 2020 would be entirely carried on with distance learning. Due to the increase in cases, the 2020 fall and 2021 spring terms continued with distance education. Accordingly, students were asked to quarantine themselves voluntarily at home (Erkut, 2020; Karadağ \& Yücel, 2020).
In studies performed on university students during the COVID-19 pandemic, it has been highlighted that, as in the case of outbreaks such as SARS (Severe Acute Respiratory Syndrome) and MERS (Middle East Respiratory Syndrome), the COVID-19 pandemic gave rise to disorders such as global concern, fear, threat, anxiety, depression, suicide and post-traumatic stress disorder in association with the fear of being infected and infecting others, increase in the number of cases across countries, sensational and fake news on social media, economic setbacks, fall in the communication between people, travel restrictions, distance learning, being estranged from friends and the school environment, academic failure, social isolation, changes in sleeping and eating patterns, trouble in concentrating, and uncertainty about education processes (Garfin, Silver \& Holman, 2020; Liu, 2020; Xiao, 2020; Cao, 2020). It was asserted that, since the internships and practical studies of students enrolled at health-related programs of tertiary education institutions were put on hold at clinics, they were more affected by the COVID-19 pandemic than students studying at other programs, and they suffered the highest levels of anxiety and stress associated with uncertainty (Liu, 2020). It is considered that nursing students who will be the members of the profession of nursing in the future are members of a special group whose mental health status should not be neglected during the quarantine period, as nurses are healthcare professionals serving in the frontlines in the field during outbreaks.

This study was conducted to determine the relationship between Turkish nursing students' intolerance of uncertainty and their depression, anxiety and stress levels during the COVID-19 outbreak.

\section{Research Questions}

1. What are the intolerance of uncertainty, depression, anxiety and stress levels of nursing students?

2. Which factors influence the levels of intolerance of uncertainty, depression, anxiety and stress in nursing students?

3. Is there a relationship between nursing students' intolerance of uncertainty and their depression, anxiety and stress levels? 


\section{Design and Methods}

1. Design: This study was conducted with a descriptive and cross-sectional design.

2. Setting and Sample: The population of the study consisted of all nursing students who are first, second, third and fourth year students in a university $(\mathrm{N}=584)$. The study included nursing students (a) who were receiving nursing education in the spring term of the academic year of 2019-2020, (b) who had no hearingrelated or visual problems, (c) who were open to communication, (d) who could read and speak Turkish, (e) who agreed to participate in the study. The voluntary participation rate in the study was $86.6 \%$ $(\mathrm{n}=506)$.

\section{Data Collection Instruments}

The data were collected by using a Personal Information Form, the Intolerance of Uncertainty Scale (IUS) (Sarıçam et al., 2014) and the Depression Anxiety Stress Scale-21 (DASS-21) (Yılmaz, Boz \& Arslan, 2017).

\subsection{Personal Information Form}

The researchers prepared the form with the support of the literature (Wright, Adams Lebell \& Carleton, 2016; Cao et al., 2020; Huang, Xu \& Liu, 2020; Kamal \& Othman, 2020; Liu, Liu \& Zhong, 2020; Lee, 2020; Pragholapati, 2020). The form consisted of 11 closed-ended questions about the participants' socio-demographic characteristics such as age, gender, class year, instruction type, academic achievement, economic status, place of living, how they felt during the COVID-19 pandemic, status of having any chronic disease, status of having any psychiatric disease, and status of thinking they took the necessary measures during the COVID-19 pandemic.

\subsection{Intolerance of Uncertainty Scale (IUS-12)}

The scale was created in 2007 by Carleton, Norton and Asmundson. It was adapted into Turkish by Sarıçam (2014). It is a 5-point Likert-type scale comprising 12 items. The scale has two sub-scales, and the total score of the scale is used for assessment. The first item of the scale is inversely scored. The total score to be obtained from the scale ranges between 12 and 60 points. The scale has no cut-off point. A high score signifies a high level of intolerance of uncertainty. The Cronbach's Alpha coefficient of the scale was reported as 0.88 (Sarıçam, 2014). In this study, the Cronbach's Alpha coefficient of the scale was found as 0.848 .

\subsection{Depression, Anxiety and Stress Scale-21 (DASS- 21)}

The Depression, Anxiety and Stress Scale (DASS-21), which was developed by Lovibond and Lovibond (1995), was originally composed of 42 items. Later on, Henry and Crawford (2005) created its short version containing 21 items. The short version of the scale was adapted into Turkish by Y1lmaz, Boz and Arslan (2017). The DASS21 employed in this study comprises 7 items in each of its sub-scales (items 3, 5, 10, 13, 16, 17 and 21 for the 'depression' sub-scale, items 2, 4, 7, 9, 15, 19 and 20 for the 'anxiety' sub-scale and items 1, 6, 8, 11, 12, 14 and 18 for the 'stress' sub-scale), that is, a total of 21 items.
The scale is scored as a 4-point Likert-type scale. A high score in the overall scale reveals in which of the 'depression', 'anxiety' and 'stress' sub-scales the individual has problems. In this study, the Cronbach's Alpha coefficients were found as 0.907, 0.806, 0.912 and 0.833 successively for the 'depression' sub-scale, the 'anxiety' sub-scale, the 'stress' sub-scale and the overall DASS-21.

\section{Data Collection}

The data were collected between 18 and 29 May 2020. Due to the COVID-19 pandemic process, the Personal Information Form, IUS-12 and DASS-21 were applied to all students via the Google Forms platform. The Google Forms link of the data collection instruments was shared by class representatives from WhatsApp groups, where all students were registered: https://docs.google.com/forms/d/1DnsPHCsGZJgOzHJE 52XgguZTDm9qDVNq7AnOp31Z2Cc/edit. Information was provided about the purpose of the study and its voluntary basis of participation via the Google Forms platform. At the end of the data collection process, the Google Forms link was closed to access. The questionnaire form including all data collection instruments took about 5 to 10 minutes to answer.

\section{Data analysis}

The data were entered into the SPSS 21.0 (Statistical Package for the Social Sciences, Chicago, Illinois) package program and analyzed. The categorical variables are presented as frequency and percentage. The continuous variables are presented as mean and standard deviation (SD). The normality of data distribution was evaluated with Shapiro-Wilk test or KolmogorovSmirnov test. Independent-Samples t-Test was used to compare two groups, whereas one-way analysis of variance (ANOVA) was used to compare more than two groups. The Cronbach's alpha coefficient was calculated for reliability analysis. Pearson's correlation analysis was used to determine the relationship between the scales. The $\mathrm{p}$-value for significance was accepted as $<0.05$.

\section{Ethical approval}

Ethics committee approval for the study was received from the $\mathrm{X}$ University Non-Interventional Clinical Studies Ethics Committee (Decision Number: GO 2020/122) and the Scientific Research Platform of the Ministry of Health (Protocol number: 2020-0507T12_04_32). The consent of the students who took part in the study was obtained via Google Forms. Additionally, written permission was obtained from the scale developers to use the scales. This study was carried out by considering the Good Clinical Practices of the Declaration of Helsinki.

\section{Results}

The breakdown of the nursing students by their sociodemographic characteristic is presented in Table 1 . As seen in Table 1 , among all nursing students, $51.6 \%$ were aged $20-21$ years, $72.1 \%$ were female, $29.3 \%$ were firstyear students, and $70.6 \%$ had medium-level academic achievement. Besides, of all nursing students, $80.4 \%$ had income equaling their expenses, $43.9 \%$ spent the longest period of their lives in the provincial center, and $33.4 \%$ 
felt uneasy during the COVID-19 pandemic. Furthermore, of all participant nursing students, 5.3\% reported that they had a chronic disease, $3.8 \%$ stated that

Table 1.

Socio-Demographic Characteristic of Nursing Students'

\begin{tabular}{|c|c|c|c|}
\hline Socio-Demographic Characteristic $(\mathrm{n}=506)$ & & $\mathbf{N}$ & $\%$ \\
\hline \multirow{3}{*}{ Age } & $18-19$ years & 91 & 18.0 \\
\hline & $20-21$ years & 261 & 51.6 \\
\hline & 22 years or above & 154 & 30.4 \\
\hline \multirow[t]{2}{*}{ Gender } & Female & 365 & 72.1 \\
\hline & Male & 141 & 27.9 \\
\hline \multirow[t]{4}{*}{ Class year } & First year & 148 & 29.3 \\
\hline & Second year & 114 & 22.5 \\
\hline & Third year & 123 & 24.3 \\
\hline & Fourth year & 121 & 23.9 \\
\hline \multirow[t]{2}{*}{ Instruction type } & Formal education & 323 & 63.8 \\
\hline & Evening education & 183 & 36.2 \\
\hline \multirow[t]{3}{*}{ Academic achievement } & Unsuccessful & 46 & 9.1 \\
\hline & Medium level & 357 & 70.6 \\
\hline & Successful & 103 & 20.4 \\
\hline \multirow[t]{2}{*}{ Economic situation } & Income equals expenses & 407 & 80.4 \\
\hline & Expenses exceed the income & 99 & 19.6 \\
\hline \multirow[t]{3}{*}{ Place of living } & Province center & 222 & 43.9 \\
\hline & District & 184 & 36.4 \\
\hline & Village/town & 100 & 19.7 \\
\hline \multirow[t]{5}{*}{ How do you feel yourself during COVID-19 pandemic? } & Uneasy & 169 & 33.4 \\
\hline & Frightened & 58 & 11.5 \\
\hline & Angry/indignant & 71 & 14.0 \\
\hline & Sad & 106 & 20.9 \\
\hline & Calm & 102 & 20.2 \\
\hline \multirow[t]{2}{*}{ Having any chronic disease } & Yes & 27 & 5.3 \\
\hline & No & 479 & 94.7 \\
\hline \multirow[t]{2}{*}{ Having any psychiatric disease } & Yes & 19 & 3.8 \\
\hline & No & 487 & 96.2 \\
\hline Do you think you took necessary measures during COVID- & Yes & 378 & 74.7 \\
\hline 19 pandemic? & No & 128 & 25.3 \\
\hline
\end{tabular}

It was found that the mean scores of obtained by the participants in the DASS-21 'depression', 'anxiety' and 'stress' sub-scales were respectively $13.20 \pm 5.87$ (min$\max$ : 7.00-28.00), 10.76 \pm 3.94 (min-max: 7.00-27.00) and $14.21 \pm 5.90$ (min-max: 7.00-28.00). Besides, it was ascertained that the participants' mean scores in the overall IUS-12 and its sub-scales of 'prospective intolerance of uncertainty' and 'inhibitory intolerance of uncertainty' were successively $37.18 \pm 10.10$ (min-max: 12.00-60.00), 22.45 \pm 5.82 (min-max: 7.00-35.00) and $14.72 \pm 5.08$ (min-max: 5.00-25.00).

It was found that the mean score of the participants aged 18-19 years the DASS-21 'depression' sub-scale was higher than that of those aged $20-21$ years $(\mathrm{p}=0.029)$.

The mean of score of the female participants in the DASS-21 'stress' sub-scale was higher than that of the male participants $(\mathrm{p}=0.028)$. Upon the examination of the participants based on their academic achievement levels, it was ascertained that the participants who were categorized as successful had significantly lower mean scores in the DASS-21 'depression' sub-scale, 'anxiety' they had a psychiatric illness, and $25.3 \%$ reported that they failed to take the necessary measures during the COVID-19 pandemic. 
$(\mathrm{p}=0.019 ; \mathrm{p}=0.003 ; \mathrm{p}=0.018)$. It was found that the participants thinking that they took the necessary measures during the COVID-19 pandemic had significantly lower mean scores in the DASS-21 'depression' sub-scale, 'anxiety' sub-scale and 'stress' sub-scale than those thinking the opposite $(\mathrm{p}=0.012$; $\mathrm{p}=0.001 ; \mathrm{p}=0.021$ ).

\section{Table 2.}

DASS-21 and IUS-12 mean scores according to some variables of nursing students'

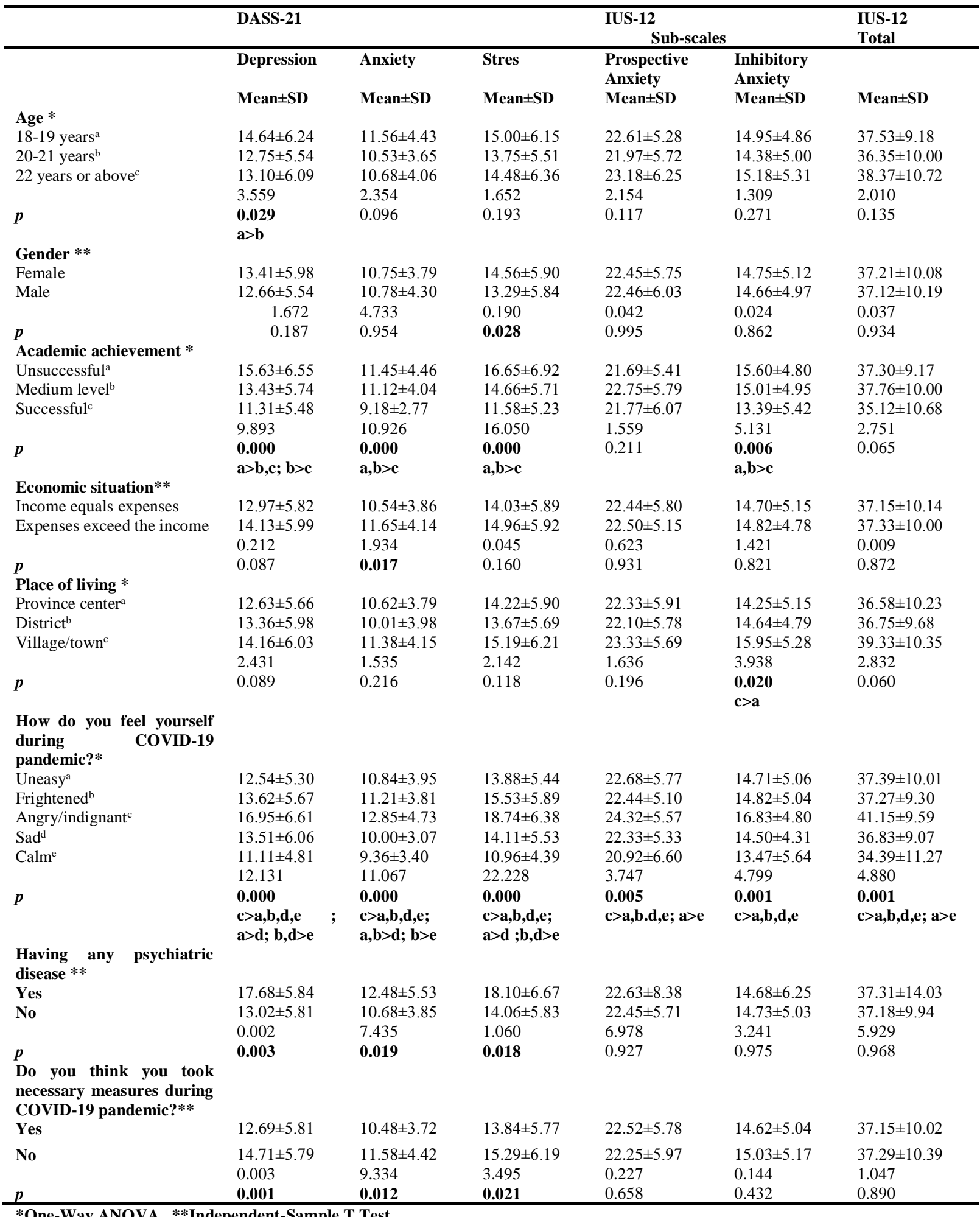

*One-Way ANOVA, **Independent-Sample T Test

Table 3 shows the breakdown of the participants' depression, anxiety and stress levels. As seen in Table 3, among all participants, $39.3 \%$ exhibited symptoms of very advanced depression, $54.1 \%$ exhibited symptoms of very advanced anxiety, and $31.6 \%$ exhibited symptoms of very advanced stress. 
Table 3.

Depression, anxiety and stress levels in nursing students'

\begin{tabular}{|c|c|c|c|c|c|c|}
\hline \multicolumn{7}{|c|}{ DASS-21 } \\
\hline & Depression & & Anx & & Stres & \\
\hline & $\mathbf{n}$ & $\%$ & $\mathbf{n}$ & $\%$ & $\mathbf{n}$ & $\%$ \\
\hline Normal & --- & --- & --- & --- & 85 & 16.8 \\
\hline Mild & --- & --- & --- & --- & 47 & 9.3 \\
\hline Middle & 216 & 42.7 & 130 & 25.7 & 99 & 19.6 \\
\hline Advanced & 91 & 18.0 & 102 & 20.2 & 115 & 22.7 \\
\hline Very Advanced & 199 & 39.3 & 274 & 54.1 & 160 & 31.6 \\
\hline
\end{tabular}

The correlation analysis of the scores obtained by the participants in DASS-21 and IUS-12 is displayed in Table 4. As shown in Table 4, there was a weak positive statistically significant relationship between the mean scores obtained by the participants in the IUS-12 'prospective intolerance of uncertainty' sub-scale and their mean scores in the DASS-21 'depression', 'anxiety' and 'stress' sub-scales. Likewise, there was a weak positive statistically significant relationship between the

\section{Table 4.}

Correlation analysis of the scores DASS-21 and IUS-12 nursing students

\begin{tabular}{|c|c|c|c|c|c|c|}
\hline & \multicolumn{4}{|c|}{ DASS-21 } & & \\
\hline & \multicolumn{2}{|c|}{ Depression } & \multicolumn{2}{|c|}{ Anxiety } & \multicolumn{2}{|c|}{ Stres } \\
\hline & $\mathrm{r}$ & $\mathrm{p}$ & $\mathrm{r}$ & $\mathrm{p}$ & $\mathrm{r}$ & $\mathrm{p}$ \\
\hline Prospective Anxiety & 0.240 & 0.000 & 0.172 & 0.000 & 0.289 & 0.000 \\
\hline Inhibitory Anxiety & 0.344 & 0.000 & 0.262 & 0.000 & 0.370 & 0.000 \\
\hline IUS-12 Total & 0.312 & 0.000 & 0.231 & 0.000 & 0.353 & 0.000 \\
\hline
\end{tabular}

Pearson correlation

\section{Discussion}

This study indicates that more than half of the nursing students had advanced and very advanced levels of depression, anxiety and stress. In the relevant literature, it has been asserted that the COVID-19 pandemic affected the psychological statuses of university students adversely, and university students had depression, anxiety, stress, fear and worry on varying levels (Liu, 2020; Cao et al., 2020; Huang, 2020; Ozamiz-Etxebarria, Dosil-Santamaria, Picaza-Gorrochategui, \& IdoiagaMondragon, 2020; Savitsky, Findling, Ereli, \& Hendel, 2020).

The results of this study were analogous to those in the relevant literature, and according to the relevant literature, it is considered that nursing students had psychological problems due to the fact that they were obliged to comply especially with the call to 'stay at home', felt professionally incompetent for not being able to perform their clinical practices, got distanced from friends, and also owing to the continuation of the distance-learning process along with the continuation of the pandemic, they were worried about videos spreading across social media and had concerns about employment and finding a job (Kürtüncü \& Kurt, 2020; OzamizEtxebarria, 2020).

In this respect, it may be recommended to perform necessary psychological interventions on students.In this study, it was found that the nursing students' overall IUS12 scores were above average. In the studies by Satici. (2020a) and Bakioglu et al. (2020), it was reported that individuals with high levels of fear of COVID-19 also had high levels of intolerance of uncertainty. mean scores obtained by the participants in the IUS-12 'inhibitory intolerance of uncertainty' sub-scale and their mean scores in the DASS-21 'depression', 'anxiety' and 'stress' sub-scales. Moreover, it was identified that there was a weak positive statistically significant relationship between the mean scores of the participants in the overall IUS-12 and their mean scores in the DASS-21 'depression', 'anxiety' and 'stress' sub-scales. 
Etxebarria, 2020; Kamal \& Othman, 2020), there are studies indicating that gender was not associated with changes in stress levels (Liu, 2020; Zhang, 2020).

Although there are divergent studies on gender in the relevant literature, it is considered that this result was associated with the fact that the majority of the sample this study were female nursing students, the female nursing students' methods of coping with stress had shortcomings due to the psychological effect of the pandemic, and the female students were under higher risk of depression.

It was found that those living in villages or towns had higher inhibitory intolerance of uncertainty than those living in the provincial center.

Likewise, in the study performed by Cao (2020) on students at a school of medicine, it was reported that students living in rural areas had higher levels of anxiety than those living in urban areas.

In the study carried out by Huang (2020) on nurses and nursing students, it was identified that those living in rural areas had higher levels of sadness than those living in urban areas, and those living in urban areas had higher levels of anxiety and anger than those living in rural areas.

This situation may be explained with the imbalance between urban and rural areas in terms of economic, cultural and educational resources.

It is thought that the students living in urban areas had access to more comprehensive information on the fight against the pandemic and had more advantages in accessing protective equipment and health services than the students living in rural areas.

In this study, it was found that the nursing students with income levels below their expenses had higher levels of anxiety.

This study was in a similar vein to the relevant literature which sets forth that students think that they will have financial difficulty in paying school fees as certain families will have economic setbacks along with job losses, they will be exposed to shortcomings in accessing the internet, and there will be interruptions in the payment of their scholarships in the process of distance learning due to economic hardships (Kürtüncü \& Kurt, 2020; Cao, 2020; Kılınçel, 2020a).

This situation might have accordingly raised the students' anxiety levels. It may be recommended that students who are living in rural areas and those with no internet access and computers are supported by universities for securing equal access to education.

In this study, it was found that the nursing students who were categorized as unsuccessful and those with medium academic achievement levels had higher mean DASS-21 'depression' sub-scale, 'anxiety' sub-scale and 'stress' sub-scale scores and IUS-12 'inhibitory intolerance of uncertainty' sub-scale scores than the nursing students who were categorized as successful.

This study was in a similar vein to the relevant literature which puts forward that students with low academic achievement levels had trouble in focusing on their studies and were exposed to negative psychological effects for a number of reasons such as the uncertainty of the process, exam format, fear of getting low grades, absence of internet connection and computers in the distance-learning process and concerns about selfprotection (Cao, 2020; Lee, 2020; Wang, 2020; Kürtüncü \& Kurt, 2020).

In this study, it was determined that the students with any psychiatric disease had higher levels of depression, anxiety and stress. In the relevant literature, it has been stated that individuals with psychiatric diseases would be more affected by emotional reactions brought about by the COVID-19 pandemic, and this in turn would give rise to the recurrence or aggravation of an already existing psychiatric health condition due to being more susceptible to high levels of stress than the general population (Yao, Chen \& Xu, 2020; Druss, 2020; Kozloff, Mulsant, Stergiopoulos, \& Voineskos, 2020).

It may be recommended for educational institutions to offer psychiatric support especially to students known to have psychiatric problems.

In this study, it was determined that the nursing students who thought that they took the necessary measures during the COVID-19 pandemic had lower levels of depression, anxiety and stress.

The results of this study were compatible with those reported in the relevant literature (Ekiz, Ilıman \& Dönmez, 2020; Bostan, Erdem, Öztürk, Kılıç, \& Yılmaz, 2020; K1lınçel, 2020).

It is considered that the measures taken properly by the nursing students against the COVID-19 pandemic were some of the most important elements in preventing the nursing students from having psychiatric disorders.

In this study, there was a weak positive statistically significant relationship between the mean overall IUS-12 scores of the participants and their mean DASS-21 'depression' sub-scale, 'anxiety' sub-scale and 'stress' sub-scale scores. It was deduced that the nursing students with high intolerance of uncertainty had higher levels of depression, anxiety and stress.

This study was in parallel with the relevant literature, where it has been asserted that a negative emotion triggers other negative emotions and aggravates the situation even further, and in tandem with growing fear and uncertainty, individuals have increased levels of depression, anxiety and stress intolerance (Bakioğlu, 2020; Harper, Satchell, Fido, \& Latzman, 2020; Satici, 2020a; Satici, Saricali, Satici, \& Griffiths, 2020; Taylor, 2020).

\section{Conclusion}

As the intolerance of uncertainty of the nursing students who participated in this study increased, their depression, anxiety and stress levels also increased.

The negative effects of severe depression, anxiety and stress on nursing education and the psychological wellbeing of nursing students in the pandemic period should be considered.

In light of these results, it is recommended to raise nursing students' levels of knowledge and awareness about contagious diseases with accurate and filtered information through social media channels, to increase the number of practical courses offered through distance 
learning following the pandemic and hence eliminate the perception of incompetence likely to be developed by students, for universities and governments to solve challenges faced by students in issues such as having access to an internet connection and a computer during distance learning, for university administrations to constantly be in dialogue with students and make explanations on all relevant topics, to teach students about positive coping methods (e.g., breathing techniques, meditation) for coping with the stress, and to create free online psychological consultancy units within universities and the government.

\section{Limitations}

There were a few limitations to this study. This study did not represent the entire body of nursing students in Turkey and was limited to nursing students who were receiving education at the university where the study was conducted.

Additionally, the students who participated in the study needed an internet connection and technological infrastructure such as computers and telephones to complete the survey. Those without an internet connection or technological infrastructure could not be included in the study.

\section{Declarations}

Ethics Approval and Consent to Participate

Ethics committee approval was gained from the Ethics Committee for Non-Interventional Clinical Studies at Burdur Mehmet Akif Ersoy University (Decision Number: GO 2020/122) and the Scientific Research Platform of the Ministry of Health (Protocol number: 2020-05-07T12_04_32).

\section{Consent for Publication}

Not applicable.

\section{Availability of Data and Materials}

The datasets used and/or analyzed in this study can be obtained from the corresponding author upon reasonable request.

\section{Funding}

The authors did not receive any financial support in conducting this study.

\section{Declaration of Conflicting Interests}

The authors declare no potential conflicts of interest with respect to the research, authorship and/or publication of this article.

\section{Authors' Contributions}

Concept -S.Ş., N.B.; Design - S.Ş., N.B.; Supervision - S.Ş., N.B.; Resource - S.S.., N.B.; Materials -S.S.; Data Collection and/or Processing -S.S.,; Analysis and/or Interpretation - N.B.,; Literature Search - S.Ş., N.B.; Writing - S.Ş, N.B.; Critical Reviews - S.Ş, N.B.; Other - S.Ş., N.B.

\section{Acknowledgments}

The authors would like to thank all participants.

\section{References}

Antony, M. M., Bieling, P. J., Cox, B. J., Enns, M. W., \& Swinson, R. P. (1998). Psychometric properties of the 42 -item and 21 -item versions of the depression anxiety stress scales in clinical groups and a community sample. Psychological Assessment, 10(2), 176-181.

Bakioğlu, F., Korkmaz, O., \& Ercan, H. (2020). Fear of COVID19 and positivity: mediating role of intolerance of uncertainty, depression, anxiety, and stress. International Journal of Mental Health and Addiction, 1-14.

Bostan, S., Erdem, R., Öztürk, Y. E., Kılıç, T. \& Yılmaz, A. (2020). The effect of COVID-19 pandemic on the Turkish Society. Electronic Journal of General Medicine, 17(6), em237.

Cao, W., Fang, Z., Hou, G., Han, M., Xu, X., Dong, J., \& Zheng, J. (2020). The psychological impact of the COVID-19 epidemic on college students in China, Psychiatry Research 287, 112934.

Carleton, R. N., Sharpe, D., \& Asmundson, G. J. G. (2007). Anxiety sensivity and intolerance of uncertainity: requisites of the fundamental fears? Behavior Research and Therapy, 45, 2307-2316.

Druss, B. G. (2020). Addressing the COVID-19 pandemic in populations with serious mental illness. JAMA Psychiatry, 77(9), 891-892.

Ekiz, T., Ilıman, E., \& Dönmez, E. (2020). Comparison of health anxiety level and control perception of COVID-19. International Journal of Health Management and Strategies Research, 6(1), 139-154.

Erkut, E. (2020). Higher education after COVID-19. Journal of Higher Education, 1-9.

Garfin, D. R., Silver, R. C., \& Holman, E. A. (2020). The novel coronavirus (COVID-2019) outbreak: amplification of public health consequences by media exposure. Health Psychology, 39(5), 355-357.
Harper, C. A., Satchell, L. P., Fido, D., \& Latzman, R. D. (2020). Functional fear predicts public health compliance in the COVID-19 pandemic. International Journal of Mental Health Addiction, 1-14.

Henry, J. D., \& Crawford, J. R. (2005). The short-form version of the depression anxiety stress scales (DASS-21): construct validity and normative data in a large non-clinical sample. British Journal of Clinical Psychology, 44(2), 227-39.

Huang, C., Wang, Y., Li, X., Ren, L., Zhao, J., Hu, Y.I., ........ \& Cao, B. (2020). Clinical features of patients infected with 2019 novel coronavirus in Wuhan, China. The Lancet, 395 (10223), 497-506.

Huang, L., Xu, F., \& Liu, H. (2020). Emotional responses and coping strategies of nurses and nursing college students during COVID-19 outbreak. MedRxiv. https://doi.org/10.1101/2020.03.05.20031898

Kamal, N. M., \& Othman, N. (2020). Depression, anxiety, and stress in the time of COVID-19 pandemic in Kurdistan region, Iraq. Kurdistan Journal of Applied Research, 5(3), 37-44.

Karadağ, E., \& Yücel, C. (2020). Distance education at universities during the novel coronavirus pandemic: an analysis of undergraduate students' perceptions. Journal of Higher Education, 1-12.

Kılınçel, Ş., Kılınçel, O., Muratdagı, G., Aydın, A., Usta, Miraç Barıș. (2020a). Factors affecting the anxiety levels of adolescents in home-quarantine during COVID-19 pandemic in $\begin{array}{lll}\text { Turkey. Asia-Pacific } & \text { Psychiatry. }\end{array}$ https://doi.org/10.1111/appy.12406.

Kılınçel, Ş., Tuncer Issı, Z., Kılınçel, O., Akpınar Aslan, E., Ay, R., Erzin, G., ......\& Akkaya, C. (2020b). Effects of coronavirus (COVID-19) pandemic on health anxiety levels of healthcare professionals. Journal of Contemporary Medicine, 10(3), 312-318. 
Kozloff, N., Mulsant, B. H., Stergiopoulos, V., \& Voineskos, A. N. (2020). The COVID-19 global pandemic: implications for people with schizophrenia and related disorders. Schizophrenia Bulletin, 46(4), 752-757.

Kürtüncü, M., \& Kurt, A. (2020). Problems of nursing students in distance education in the COVID-19 pandemia period. Eurasian Journal of Researches in Social and Economics, 7(5), 66-77.

Liu, J., Zhu, Q., Fan,W., Makamure, J., Zheng, C., \& Wang, J. (2020). Online mental health survey in a medical college in China during the COVID-19 outbreak. Frontiers in Psychiatry, $11,1-6$.

Liu, X., Liu, J., \& Zhong, X. (2020). Psychological state of college students during COVID-19 epidemic. SSRN Electronic Journal, https://doi.org/10.2139/ssrn.3552814.

Lee, J. (2020). Mental health effects of school closures during COVID-19. The Lancet Child and Adolescent Health, 4(6), 421.

Lovibond, P. F., \& Lovibond, S. H. (1995). The structure of negative emotional states: comparison of the depression anxiety stress scales (DASS) with the Beck depression and anxiety inventories. Behaviour Research and Therapy, 33(3), 335-343.

Ozamiz-Etxebarria, N., Dosil-Santamaria, M., PicazaGorrochategui, M., \& Idoiaga-Mondragon, N. (2020). Stress, anxiety, and depression levels in the initial stage of the COVID19 outbreak in a population sample in the northern Spain. Cadernos De Saúde Pública, 36(4), 1-9.

Pragholapati, A. (2020). COVID-19 impact on students. EdArXiv Preprints, 1-6.

Republic of Turkey Ministry of Health. (2021). Current Situation in Turkey. Retrieved May 19, 2021, from Republic of Turkey Ministry of Health website: https://covid19.saglik.gov.tr/

Sarıçam, H., Erguvan, F. M., Akın, A., \& Akça, M. Ş. (2014). The Turkish short version of the intolerance of uncertainty (IUS12) scale: the study of validity and reliability. Route Educational and Social Science Journal, 1(3), 148-157.

Satici, B., Gocet-Tekin, E., Deniz, M. E., \& Satici, S. A. (2020a). Adaptation of the fear of COVID-19 scale: its association with psychological distress and life satisfaction in Turkey. International Journal of Mental Health Addiction, 1-9.

Satici, B., Saricali, M., Satici, S. A., \& Griffiths, M. D. (2020b). Intolerance of uncertainty and mental wellbeing: serial mediation by rumination and fear of COVID-19. International Journal of Mental Health and Addiction, 1-12.
Savitsky, B., Findling, Y., Ereli, A., \& Hendel, T. (2020). Anxiety and coping strategies among nursing students during the COVID-19 pandemic. Nurse Education in Practice, 46, 1-7.

Taylor, S., Landry, C., Paluszek, M., Fergus, T. A., Mckay, D., \& Asmundson, G. J. G. (2020). Development and initial validation of the COVID stress scales. Journal of Anxiety Disorders, 72, 102232

Wang, C., Pan, R., Wan, X., Tan, Y., Xiu, L., Ho, C.S., \& Ho, R. C. (2020). Immediate psychological responses and associated factors during the initial stage of the 2019 coronavirus disease (COVID-19) epidemic among the general population in China. International Journal of Environmental Research and Public Health, 17, 1729

WHO. (2021). Coronavirus. Retrieved May 19, 2021, from World Health Organization (WHO) website: https://www.who.int/health -topics/coronavirus\#tab=tab_1

Wright, K. D., Adams Lebell, M. A. N., \& Carleton, R. N. (2016). Intolerance of uncertainty, anxiety sensitivity, health anxiety, and anxiety disorder symptoms in youth. Journal of Anxiety Disorders, 41, 35-42.

Xiao, C. (2020). A novel approach of consultation on 2019 novel coronavirus (COVID-19)-related psychological and mental problems: structured letter therapy. Psychiatry Investigation 17(2), 175-176.

Yao, H., Chen, J-H., \& Xu, Y-F. (2020). Patients with mental health disorders in the COVID-19 epidemic. The Lancet Psychiatry, 7(4), 21.

Yıldız, B., \& Güllü, A. (2018). The relationship between intolerance of uncertainty and alexithmia and investigation by some socio-demographic variables. Journal of Educational Sciences, 9(1), 113-131.

Yllmaz, Ö., Boz, H., \& Arslan, A. (2017). The validity and reliability of depression stress and anxiety scale (DASS21) Turkish short form. Research of Financial Economic and Social Studies, 2(2), 92-104.

Zhang, W. R., Wang, K., Yin, L., Zhao, W. F., Xue, Q., Peng, M. .....\& Wang, H-x. (2020). Mental health and psychosocial problems of medical health workers during the COVID-19 epidemic in China. Psychotherapy and Psychosomatic, 1-9.

Zhu, H., Wei, L., \& Niu, P. (2020). The novel coronavirus outbreak in Wuhan, China. Global Health Research and Policy, $5(6), 1-3$. 